・论坛・ 中国国家公园试点专题

\title{
三江源国家公园执法体制改革经验及其可复制性
}

\author{
苏红巧 ${ }^{1}$, 王楠 ${ }^{2 *}$, 苏杨 ${ }^{1}$
}

1. 国务院发展研究中心管理世界杂志社, 北京 100026; 2. 国家林业和草原局退耕还林还草工程管理中心, 北京 100714

苏红巧，王楠，苏杨 (2021) 三江源国家公园执法体制改革经验及其可复制性. 生物多样性, 29, 304-306. doi: 10.17520/biods.2021047.

Su HQ, Wang N, Su Y (2021) The experience and its reference study of law enforcement system of Sanjiangyuan National Park pilot. Biodiversity Science, 29, 304-306. doi: 10.17520/biods.2021047.

\section{The experience and its reference study of law enforcement system of Sanjiangyuan National Park pilot}

Hongqiao $\mathrm{Su}^{1}$, Nan Wang ${ }^{2 *}$, Yang $\mathrm{Su}^{1}$

1 Management World Journal Press, Development Research Center of the State Council, Beijing 100026

2 Project Management Center for Conversion of Farmland to Forests and Grasses, National Forestry and Grassland Administration, Beijing 100714

执法是实现依法行政的最终环节, 是国家公园 管理机构实现管理目标的重要工具, 统一执法是我 国国家公园管理体制改革中“统一”的重要方面。《建 立国家公园体制总体方案》(以下简称《总体方案》) 明确, 国家公园体制建设需要坚持将 “山水林田湖 草作为一个生命共同体, 统筹考虑保护与利用”。国 家公园管理机构要实现对山水林田湖草这一生命 共同体的统一管理，执法内容会涉及到自然资源、 林业和草原、生态环境、农业农村、水利等自然资 源管理部门的执法事项。在国家公园范围内, 需要 由国家公园管理机构统一履行资源环境综合行政 执法权; 对于游客和商户众多的国家公园(如武夷 山、神农架等), 管理机构还需要有包括治安管理、 市场监管在内的更广泛的执法权。三江源是由原中 央全面深化改革领导小组通过试点方案的第一个 国家公园体制试点区, 各方面的改革也走在了试点 区前列，尤其是资源环境综合执法改革方面的经验 早就纳入了《总体方案》, 且在其后与中央生态环 保综合执法体制改革、行业公安体制改革的衔接中 摸索出了既符合中央精神又契合地方需求的经验, 形成了具有三江源特点的资源环境综合执法模式, 值得总结。

\section{资源环境执法体制改革经验}

三江源国家公园建立了统一的资源环境综合 执法队伍、行政执法和刑事司法高效联动机制以及 与毗邻省份横向联合综合执法机制。

\section{1 建立了统一的资源环境综合执法队伍}

(1)建立统一的资源环境综合行政执法队伍。三 江源国家公园衔接国家公园体制试点机构设置与 属地县级政府职能转变和机构改革, 建立了统一的 资源环境综合行政执法队伍。三江源国家公园体制 改革过程中，整合设立三江源国家公园管理局和长 江源、黄河源和澜沧江源3个园区管委会(长江源区 管委会派出治多管理处、曲麻莱管理处、可可西里 管理处 3 个正县级机构), 形成“一园三区”统一管理 机构。并整合 3 个园区涉及 4 个县的国土资源、林业 资源、水政水资源、环境保护等资源环境管理部门, 设立生态环境和自然资源管理局; 相应整合 4 个县 国土、环境、草原、渔政等部门的执法机构, 设立 资源环境执法局, 开展县域集中统一高效的资源环 境综合行政执法, 解决了政出多门、标准不一、职 能交叉、推诿扯皮、保护合力不强等问题。

同时, 三江源国家公园通过《三江源国家公园 
条例(试行)》(以下简称《条例》) 将这一执法机制制 度化。《条例》第十九条规定, “三江源国家公园设 立资源环境综合执法机构, 履行资源环境综合执法 职责, 承担县域园区内外林业、国土、环境、草原 监理、渔政、水资源、水土保持、河道管理等执法 工作”, 并在第七章“法律责任”部分明确, 违反《条 例》规定的行为, 由国家公园资源环境综合执法机 构进行执法。

(2)建立国家公园警察队伍。为了顺应国家宏观 层面“警是警, 政是政, 企是企”的改革方向, 青海 省将森林公安转为国家公园警察总队。考虑到三江 源国家公园管理的实际需要, 创新森林公安的管理 模式: 三江源国家公园范围内的森林公安队伍建制 上划归省公安厅, 基本工资由公安系统支出, 但是 实际工作中, 由三江源国家公园管理局对其进行实 质性的业务指导(即其工作主要由管理局安排), 这 既符合宏观的改革方向, 又保障了三江源国家公园 范围内资源保护所必需的强有力的执法队伍。此外, 在森林公安原有职责基础上, 将其执法和案件查处 权扩大到三江源国家公园和三江源自然保护区范 围内自然资源、生态环境、林草、农牧等自然资源 刑事司法领域, 形成了事实上的“生态公安”。

\section{2 建立资源环境行政执法和刑事司法高效联动 机制}

为加强行政执法和刑事司法的衔接, 三江源国 家公园管理局与青海省高级人民法院、省人民检察 院建立了生态保护司法合作机制, 开展环境资源案 件审判工作。三江源国家公园森林公安局与青海省 人民检察院侦查监督处建立联席会议制度, 积极推 进服务和保障三江源国家公园建设专项检察工作。 在三江源地区设立第一生态法庭, 即玉树州人民法 院三江源生态法庭, 为三江源国家公园生态环境保 护提供有力司法保障。另外, 成立了三江源国家公 园法治研究会并召开第一次会员代表大会, 研究会 结合三江源地区生态保护、绿色发展、民生改善、 社会稳定的实际, 有针对性地研讨体制试点中存在 的法治理论和实践问题, 把研讨成果应用到实际工 作中, 促进国家公园法治建设再上新台阶。

\section{3 建立与毗邻省份横向联合综合执法机制}

三江源国家公园管理局与毗邻省份各相邻保 护区管理机构合作，对生态探险游、非法穿越保护 区等行为进行联合监管, 查处生态环境资源类案件,
打击盗采、盗猎等违法犯罪活动。(1)强化自然保护 区联盟合作机制，加强区域生态环境保护和地区间 生态环境联防联治工作, 签订《青新藏(青海、新疆、 西藏)五大自然保护区生态环境保护协作备忘录》, 制定《青新藏五大自然保护区协作联盟章程》, 建 立跨省区执法合作机制, 着力加强青新藏三省区边 界区域的生态环境资源执法力量。(2)玉树白扎、东 仲、江西等保护分区森林公安派出所与西藏昌都市 公安局鸟东派出所二级检查站形成联席会议制度, 并签订《平安边界联防合作协议》, 通过建立青藏 两省区跨区域警务联防，信息互通、警力资源共享、 边界联防互动、执法办案互助, 联合打击边界地区 破坏生态资源违法犯罪, 实现责任共担、队伍共建、 防控联动、成果同享, 为创建和谐平安边界打下坚 实基础。另外, 组建了警务机动队, 探索建立突发 事件重大案件应急机制, 在集中优势力量、保障案 件侦破、建立应急机制等方面进行优化，提升生态 环境执法效能。

\section{资源环境执法体制存在的问题及建议}

三江源国家公园结合工作实际开展的资源环 境综合执法体制改革虽已取得积极进展, 但也仍然 存在部分问题有待继续深化改革。(1)资源环境综合 行政执法方面, 长江源可可西里管理处没有行政执 法工作机构, 森林公安机关管理体制调整前, 相关 工作由可可西里管理处森林公安局承担, 目前面临 行政执法“真空”的困境。建议在未来深化改革过程 中, 可可西里管理处增加行政执法部门和相应的编 制。(2)在国家公园警察队伍管理方面, 原先在三江 源国家公园管理局设立执法监督处(挂三江源国家 级自然保护区森林公安局、三江源国家公园森林公 安局牌子), 有13名森林公安专项编制, 但是改革之 后划转公安厅, 在管理局层面没有执法统筹管理部 门; 青海省公安厅和三江源国家公园管理局尚未建 立长效合作机制, 这一改革模式没有制度化。建议 由青海省人民政府统筹, 推动三江源管理局和青海 省公安厅继续探索国家公园警察队伍的管理模式, 建立长效合作机制。

\footnotetext{
3 资源环境执法体制改革经验借鉴

三江源国家公园的资源环境执法体制改革方 向对我国国家公园体制改革具有较强的借鉴意义,
} 
但是其中资源环境综合执法队伍的组建模式仍需 要根据各地的实际情况进行探索。其他试点区资源 环境综合执法队伍的组建, 面临国家宏观层面森林 公安改革和生态环境综合执法改革交叉等难题, 需 要探索不同的建立方式。如神农架国家公园体制试 点是整合原保护地执法队伍, 并拓展生态环境执法 内容——通过与神农架林区生态环境局签订委托 书, 行使辖区内的生态环境行政执法权; 武夷山国 家公园体制试点也是整合原保护地执法队伍, 并配 套创新司法机制——建立省级公检法司联合执法 办案协作机制, 设立南平市驻国家公园检察官办公 室; 钱江源国家公园体制试点是新组建综合行政执 法队。

既有经验表明, 资源管理和游客行为是国家公 园等自然保护地执法活动涉及到的主要方面, 保护 地管理机构与地方政府、其他部门的紧密合作是实 现管理目标的重要保障。体制试点阶段, 我国国家
公园重在关注“生态保护第一”, 多个试点区专项执 法行动针对的也都是资源环境违法行为。但是, 三 江源等盗猎活动相对比较多的试点区和武夷山、大 熊猫等游客和旅游产业相对发达试点区的经验表 明, 对盗猎等刑事犯罪行为的及时处理和因客流量 带来的治安问题也不容忽视。三江源国家公园通过 创新国家公园警察队伍管理模式解决了这类问题, 存在类似问题的其他国家公园, 需要借鉴这一经验, 探索与公安队伍的长效合作机制。未来在《国家公 园法》中需要对国家公园范围内的资源环境综合行 政执法、刑事司法和治安管理等执法主体、执法内 容和范围、执法机制等予以规定。

致谢: 特别感谢三江源国家公园管理局的赫万成和 田俊量在本文撰写过程中给予的支持和帮助。

(责任编委: 徐卫华 责任编辑: 周玉荣) 